\title{
Collagen-based silver nanoparticles for biological applications: synthesis and characterization
}

\author{
Vinicius S Cardoso ${ }^{1,2}$, Patrick V Quelemes ${ }^{1}$, Adriany Amorin ${ }^{1}$, Fernando Lucas Primo ${ }^{3}$, Graciely Gomides Gobo ${ }^{3}$, \\ Antonio C Tedesco ${ }^{3}$, Ana C Mafud ${ }^{4}$, Yvonne P Mascarenhas ${ }^{4}$, José Raimundo Corrêa ${ }^{5}$, Selma AS Kuckelhaus ${ }^{6}$, \\ Carla Eiras ${ }^{7}$, José Roberto SA Leite ${ }^{1}$, Durcilene Silva ${ }^{1}$ and José Ribeiro dos Santos Júnior ${ }^{8^{*}}$
}

\begin{abstract}
Background: Type I collagen is an abundant natural polymer with several applications in medicine as matrix to regenerate tissues. Silver nanoparticles is an important nanotechnology material with many utilities in some areas such as medicine, biology and chemistry. The present study focused on the synthesis of silver nanoparticles (AgNPs) stabilized with type I collagen (AgNPcol) to build a nanomaterial with biological utility. Three formulations of AgNPcol were physicochemical characterized, antibacterial activity in vitro and cell viability assays were analyzed. AgNPcol was characterized by means of the following: ultraviolet-visible spectroscopy, dynamic light scattering analysis, Fourier transform infrared spectroscopy, atomic absorption analysis, transmission electron microscopy and of X-ray diffraction analysis.
\end{abstract}

Results: All AgNPcol showed spherical and positive zeta potential. The AgNPcol at a molar ratio of 1:6 showed better characteristics, smaller hydrodynamic diameter (64.34 \pm 16.05$)$ and polydispersity index $(0.40 \pm 0.05)$, and higher absorbance and silver reduction efficiency $(0.645 \mathrm{mM})$, when compared with the particles prepared in other mixing ratios. Furthermore, these particles showed antimicrobial activity against both Staphylococcus aureus and Escherichia coli and no toxicity to the cells at the examined concentrations.

Conclusions: The resulted particles exhibited favorable characteristics, including the spherical shape, diameter between $64.34 \mathrm{~nm}$ and $81.76 \mathrm{~nm}$, positive zeta potential, antibacterial activity, and non-toxicity to the tested cells (OSCC).

Keywords: Silver nanoparticles, Collagen, Antimicrobial activity, Cell viability

\section{Background}

Collagen is the most abundant protein constituting to the $30 \%$ of total protein and $6 \%$ of animal body weight $[1,2]$. Type I collagen, a natural polymer, is a major extracellular matrix protein in mammals and exhibits favorable characteristics for promoting cell proliferation [3-5]. It can influence the cell physiology and morphology $[4,6]$, create a good matrix for endothelial cells in vitro, induce platelet aggregation, promote blood clotting, and consequently accelerate the healing of skin wounds [7].

\footnotetext{
* Correspondence: jribeiro@ufpi.edu.br

${ }^{8}$ Department of Chemistry, Campus Teresina, Federal University of Piauí, 64049-550 Teresina, Piauí, Brazil

Full list of author information is available at the end of the article
}

Since 1980s, some scientists have been using collagen as a matrix to regenerate tissues for repairing skin [8], bone [9], knee meniscal [10], joint cartilage [11], esophagus [12], dura mater [13], muscle [14] and nervous system [15]. The use of collagen combined with glycosaminoglycans as a skin implant has been already tested $[16,17]$. The ability of collagen gel to regenerate cornea and nerves has been also demonstrated by recent animal studies and clinical trials $[18,19]$. Furthermore, it has been shown that the combined collagen and hyaluronic acid can promote the revascularization of tissues in animal models [20].

In the field of nanotechnology, collagen scaffold has been widely used in biological experiments for introducing chemical and pharmaceutical substances. Bakare et al. [21] proposed a method for constructing a film by using poly(hydroxybutyrate valerate) (PHBV) grafted 
with scaffold tipo I collagen to support silver nanoparticles (AgNPs). Jithendra et al. [22] suggested a blend of Aloe Vera with collagen and chitosan scaffold for tissue engineering applications.

Metal nanoparticle, especially those made of noble metals, show excellent properties for biotechnology applications [23-25]. In particular, AgNPs have established a broad range of applications in the majority of biomedical studies [26], due to their antibacterial ability and selective toxicity to microorganisms [27].

In addition, AgNPs are widely used in various medical and industrial fields for venous catheters coating; vascular prostheses manufacturing; wound dressing manufacturing; treatment for chronic wounds and ulcers [25]; or as a constituent incorporated into cement for the realignment of bone fractures [27], in to water purification filter [28] and into wall paint for providing an aseptic environment to hospital patients [29].

The ability of AgNPs to control bacterial activity relies on the interactions with three major structural components of the bacteria: namely peptidoglycan in the cell wall, DNA, and proteins, by mainly affecting the enzymes involved in the electron transport chain [30-33].

The ideal properties of AgNPs for biomedical applications include prolonged effectiveness, high levels of bactericidal and bacteriostatic activity, ability to prevent a broad spectrum of bacteria, high biocompatibility, and low toxicity in vivo [33]. In particular, the shape and concentration of AgNPs in solutions are important factors in ensuring the effective contact of the particles with the bacterial membranes and in determining the amount of AgNPs for effectively inhibiting the targeting bacteria [34].

Some literatures reported the application of AgNPs for treating the wounds of mice, and these particles showed excellent tensile properties and resulted in improved alignment of fibers for skin repair $[35,36]$.

Based on the previously discussed properties and applications of collagen and AgNPs, we designed and synthesized three types of AgNPs stabilized with type I collagen (AgNPcols) by using a chemical synthesis route in the present study. This article presents their chemical synthesis, physicochemical characterization, analysis of activity against gram-positive and gram-negative bacteria, and in vitro cell viability assays.

\section{Results and discussion}

Type I collagen is the most abundant protein in mammals and is present during tissue repair [1-5,7]. Although collagen has been used in biomedical research for several years, AgNPs stabilized with collagen, as well as their biocompatibility and antibacterial properties, have been recently reported by Alarcon et al. [37]. The authors used a photochemical route for fabricating AgNPs from silver nitrate $\left(\mathrm{AgNO}_{3}\right)$, and this route was different from the chemical route employed in this study, where a reducing agent, sodium borohydride $\left(\mathrm{NaBH}_{4}\right)$, was involved. Because $\mathrm{NaBH}_{4}$ is unstable when being in contact with water at room temperature, it is necessary to stabilize $\mathrm{NaBH}_{4}$ by using ultra-pure water at low temperature $\left(4^{\circ} \mathrm{C}\right)$ and keep the solution refrigerated until use. In addition, Sun et al. [38] reported the use of $\mathrm{NaBH}_{4}$ for the synthesis AgNPs associated to a trisodium citrate solution. Thereafter, a multilayer film consisting of AgNPs and collagen in a layer-by-layer (LbL) configuration is generally constructed for stabilizing the particles.

An exclusive study on AgNPs stabilized by collagen has been reported [37]. Based on this study, we designed and synthesized three different formulations of AgNPs, at $\mathrm{AgNO}_{3}$ to $\mathrm{NaBH}_{4}$ molar ratios of 1:1, 1:6, and 1:15, by varying the concentration of $\mathrm{NaBH}_{4}$ to obtain the best silver $\left(\mathrm{Ag}^{0}\right)$ reduction result in solution. The solution at the $\mathrm{AgNO}_{3} / \mathrm{NaBH}_{4}$ molar ratio of 1:6 resulted in a final $\mathrm{Ag}^{0}$ concentration of $0.64 \mathrm{mM}$ (Table 1), as confirmed by the atomic absorption test. In the ratio of $1: 1$ between $\mathrm{AgNO}_{3}$ and $\mathrm{NaBH}_{4}$, the amount of reducer was not sufficient to reduce all molecules of silver. At ratio of 1:6 was obtained the best concentration for the chemical reaction, probably the molecules amount of $\mathrm{AgNO}_{3}$ and $\mathrm{NaBH}_{4}$ reached an optimum value for reduction. However, the ratio was 1:15 excess $\mathrm{NaBH}_{4}$ causing release of ions in solution and forming nanoparticles with hydrodynamic diameter higher by aggregation [39].

All synthesized solutions were characterized in terms of particle size, zeta potential, and polydispersity index (PDI) by dynamic light scattering (DLS) analysis. A positive potential (19.9-31.8 mV) was obtained for all AgNPcols (Table 1). This occurs due to amino group carries a positive charge and is present in AgNPcol [40,41] (Figure 1D). The hydrodynamic diameter of the nanoparticles was between $64.34 \mathrm{~nm}$ and $81.76 \mathrm{~nm}$ and PDI value was between

Table 1 Diameter, zeta potential, PDI of AgNPcols (mean \pm standard deviation) and molar concentration of silver in the solution

\begin{tabular}{lllll}
\hline & Diameter $(\mathbf{n m})$ & Zeta Potential $(\mathbf{m v})$ & PDI* $^{*}$ & [Ag] $(\mathbf{m M})$ \\
\hline AgNPcol (1:1) & $78.87 \pm 12.89$ & $31.8 \pm 0.62$ & $0.60 \pm 0.02$ & 0.434 \\
AgNPcol (1:6) & $64.34 \pm 16.05$ & $24.9 \pm 0.79$ & $0.10 \pm 0.05$ & 0.645 \\
AgNPcol (1:15) & $81.76 \pm 18.22$ & $19.9 \pm 0.4$ & $0.77 \pm 0.17$ & 0.345 \\
\hline
\end{tabular}

*PDI: polydisperity index. 


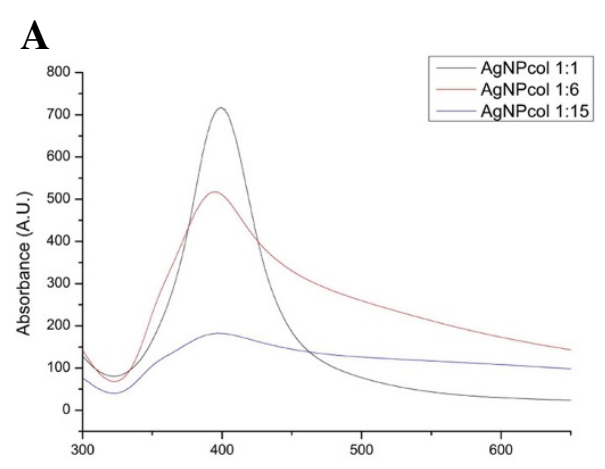

C

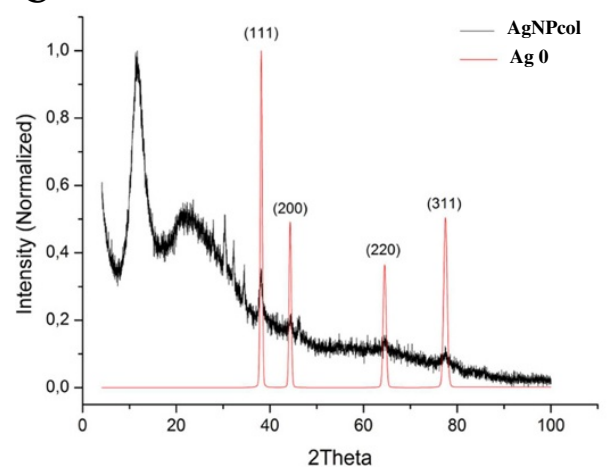

\section{B}

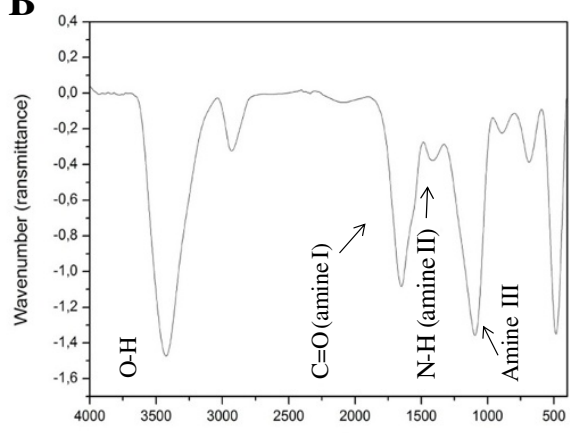

D

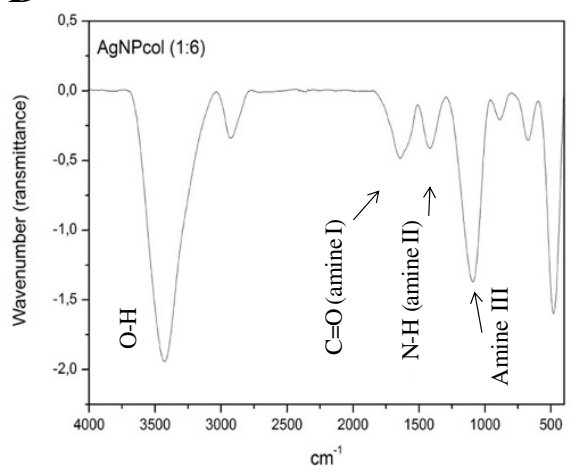

Figure 1 AgNPcol characterization. (A) Absorbance spectra of AgNPcols at three different $\mathrm{NaBH}_{4}$ to $\mathrm{AgNO}_{3}$ molar ratios; (B) FTIR spectra of collagen; (C) XDR patterns of AgNPcol (1:6 molar ratio); (D) FTIR spectra of AgNPcol (1:6 molar ratio).

0.40 and 0.77 . The AgNPs associated with titanium dioxide synthesized by Desai and Kowshik [42] showed PDI value of 0.47 , which was very close to the result obtained from this study, although other PDI values were also reported [43-45]. The value of PDI is one of the major parameters used for selecting a low-polydispersity solution for the subsequent cell viability test.

The presence of a positive zeta potential favors the interaction between the particles and Gram-negative and Gram-positive bacteria [46]. The efficiency of ionic silver against bacteria with negatively charged membranes is related to the electrostatic attraction caused by the positive potentials of the particles [47]. In the present study, the positive zeta potential of AgNPcols is one of the aspects that may explain the favorable result of its acting against E. coli and S. aureus. Hamouda and Baker [48] reported that the opposite surface charges could promote the interactions between the bacterial membranes and AgNPs. They also mentioned that, due to the small size of nanoparticles, the tested solutions could easily permeate the membranes of the bacteria and promote their death [34,49]. Furthermore, Baker et al. [50] reported that small particles with large contact areas showed increased efficiency against bacteria, as compared with the particles with large sizes. Saptarshi et al. [51] suggests that associate protein with nanoparticle, there are better cell absorption because the protein favors interaction with cell membrane facilitating interaction to nanoparticle with bacteria and another live cells.

The increase in the proportion of $\mathrm{NaBH}_{4}$ during particle synthesis could reduce the zeta potential of the resulting particles. Zhang and $\mathrm{Wu}$ [39] reported the same behavior of gold nanoparticles and claimed that this was due to the aggregation of metal particles. The AgNPcols produced in our study demonstrated similar behaviors, as indicated by the decrease in the amount of nanoparticles in the solution. This is because that the aggregated $\mathrm{Ag}^{0}$ formed larger particles, resulting in a polydisperse solution and precipitation during centrifugation. The relationship between the increases of the ratio of $\mathrm{NaBH}_{4}$ in relation to the increase in diameter of the nanoparticles is due to the release of electrons caused by $\mathrm{NaBH}_{4}$. Because when an increase occurs in the concentration of $\mathrm{NaBH}_{4}$ increases the number of free electrons in the solution and decreases the zeta potential favors the aggregation of silver [39].

After synthesis, all solutions were characterized by using ultraviolet-visible (UV-vis) spectroscopy analysis, which was efficient for detecting the sensitive AgNPs that could display a strong absorption peak [52,53]. In this study, we found a wider plasmon band and lower 
absorption peak intensity for the solution at a higher $\mathrm{NaBH}_{4}$ to $\mathrm{AgNO}_{3}$ molar ratio, as compared with the solutions at lower molar ratios (Figure 1A). It is believed that this is due to the aggregation of $\mathrm{Ag}^{\mathrm{O}}$ molecules $[53,54]$, as indicated by the values of zeta potential described above and the presence of large particles in AgNPcol at molar ratio of 1:15. We can also notice the presence of the plasmon band between $380 \mathrm{~nm}$ and $450 \mathrm{~nm}$, and this is indicative of the spherical shape of AgNPs [55], which can be further confirmed by transmission electron microscopy (TEM) analysis (Figure 2). Some researchers $[35,56]$ reported that the spherical shape is the optimal morphology for nanoparticles against bacteria, as it can facilitate the interaction between the particles and the bacterial membranes.

The difference in size AgNPcol found between the results of Table 1 (DLS) and Figure 2 (MET) occurs because the DLS diameter is measured in solution (hydrodynamic diameter value). Already in the TEM, the nanoparticle is no in solution and the result is a projected estimate of the diameter of the nanoparticle. The hydrodynamic diameter of the nanoparticles (DLS) was highlight, because this nanoparticle was developed for use in a biological environment and will be in solution [57].

From the Fourier transform infrared spectra (FTIR) of collagen and AgNPcol (1:6 molar ratio) (Figure 1B and D), we can observe the presence of $\mathrm{C}=\mathrm{O}$ (amine I at $1652.84 \mathrm{~cm}^{-1}$ ) and $\mathrm{NH}$ bands (amine II at $1571.64 \mathrm{~cm}^{-1}$ ) in both samples of collagen and AgNPcol. However, the band due to $\mathrm{C}=\mathrm{O}$ (amine $\mathrm{I}$ at $1652.84 \mathrm{~cm}^{-1}$ ) in the spectrum of AgNPcol showed a low intensity, indicating that this group was possibly involved in the reduction and stabilization of AgNPs. Sun et al. [38] suggested that these changes were due to the association of collagen molecules (i.e., amines) with AgNPs.

The phases of the samples were determined by X-ray powder diffraction (XDR) analysis by searching against databases. In Figure $1 C$, it can see the silver peaks (ICSD: 44387-Ag0), with reflections identified. Traces of silver oxides (ICSD: 35540-Ag2O, 27659-AgO, 15999/ 59193-Ag2O3, 202218-Ag3O4) were also identified from the sample. Silver oxides reflections can be found in [Additional file 1]. This result is consistent with our expectation that oxidation products can be formed on the

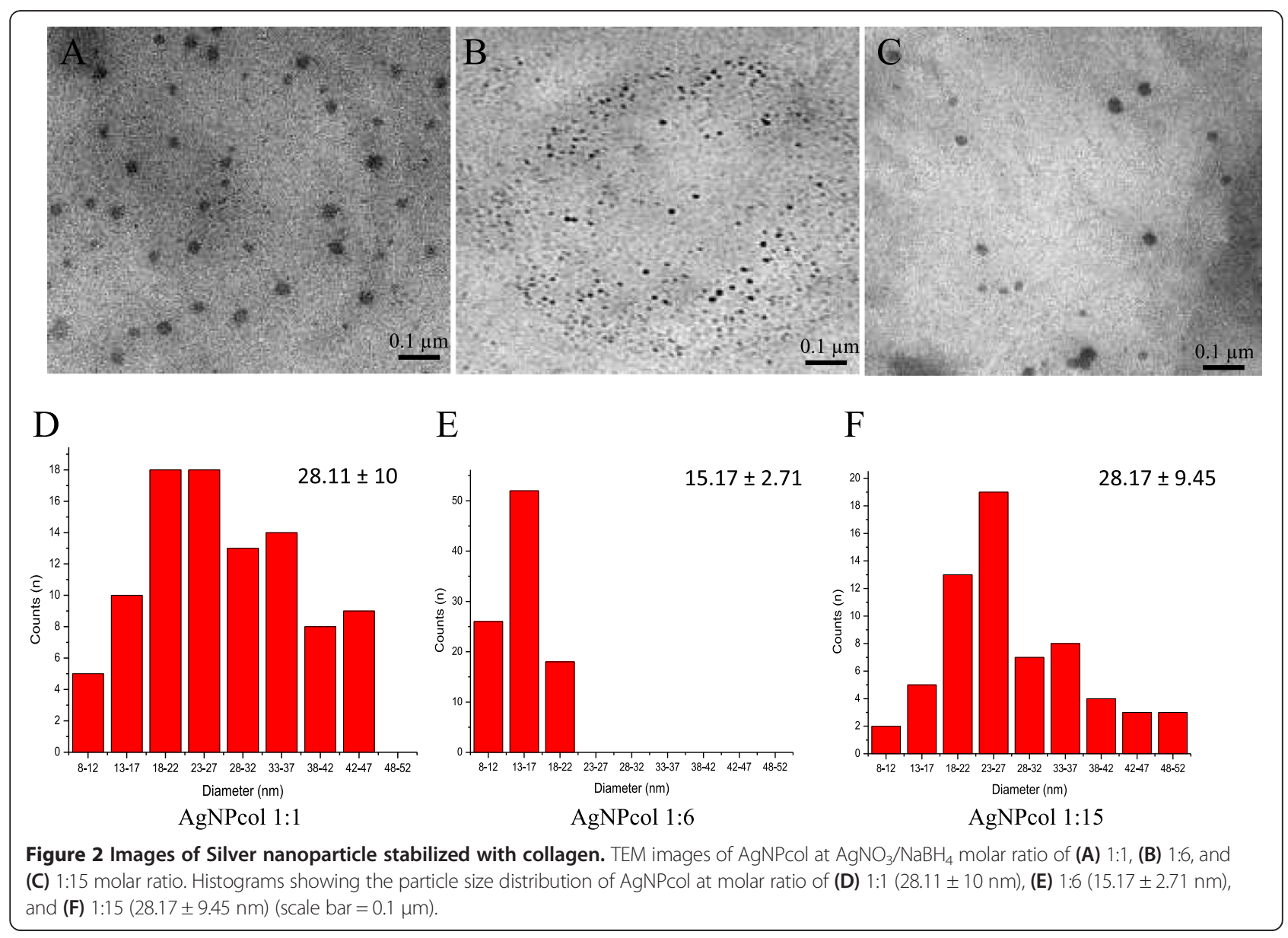


surface of pure silver. In addition, we found that the amorphous phase of collagen affected the sample's crystallinity, resulting in its semi-crystalline state.

The activity of AgNPcols against the gram-positive bacterium, Staphylococcus aureus (ATCC 29213), and gram-negative bacterium, E. coli (ATCC 25922), was tested by using an $\mathrm{AgNO}_{3}$ solution as control. Based on the results of the atomic absorption spectrometric study, the concentration of AgNPcols was corrected for the antimicrobial assays. It was found that the behavior of AgNPcol (1:6 molar ratio) for inhibiting the growth of bacteria was comparable to that of $\mathrm{AgNO}_{3}$ (Table 2). Thus, we may assume that the silver particle can maintain its antimicrobial property when being incorporated into the collagen-stabilized nanoparticles. In Alarcon's study [37] about AgNPs stabilized with collagen, was lower than that of $\mathrm{AgNO}_{3}$ used as control.

For the cell viability test, we chose only one synthesized solution by analyzing the relevant characterization data. AgNPcol at the molar ratio of 1:6 was chosen for the test, due to its smaller particle size, lower PDI, and a higher percentage of $\mathrm{Ag}^{0}$ than those of other samples, as determined by atomic absorption spectroscopy. The results (Figure 3) indicated that the AgNPcol solution at the tested concentrations did no cause significant differences in cell viability as compared with the control (CT). In addition, $\mathrm{AgNO}_{3}$ and collagen (Col) were also used for comparison. It is known that collagen does not show any cytotoxicity towards cells, as this can be evidenced by its abundance in animals and the human body. Although $\mathrm{AgNO}_{3}$ solution was reported to be toxic to cells, the AgNPcol at the approximate Ag concentration as that of $\mathrm{AgNO}_{3}$ did not show any toxicity to the cells tested in this study. We attempted to use higher concentrations of AgNPcol to evaluate its cytotoxicity; however, precipitation occurred in the solution before incubation under the physiological $\mathrm{pH}$ and ambient temperature conditions.

Gurunathan et al. [58] performed the cell viability test by using breast cancer cells (MDA-MB-23) and AgNP at $5 \mu \mathrm{g} / \mathrm{ml}$, which did not exhibit cytotoxicity as compared with the control. In addition, Prokopovich et al. [59] synthesized the AgNPs by using $\mathrm{NaBH}_{4}$, and the produced nanoparticles were incorporated into the bone cement, which did not show cytotoxicity to osteoblast cells (MC 3TC) either.

The results of the present study showed that the synthesized AgNPcol was effective against the tested bacteria and was non-toxic to the examined cells. Further tests will be conducted to evaluate the in vivo cytotoxicity and healing ability of AgNPcol by using biological tissues and animal samples.

\section{Conclusion}

In the present study, we demonstrated the synthesis of an AgNP solution stabilized with type I collagen by using $\mathrm{NaBH}_{4}$ as a reducing agent. The resulted particles exhibited favorable characteristics, including the spherical shape, diameter between $64.34 \mathrm{~nm}$ and $81.76 \mathrm{~nm}$, positive zeta potential, antibacterial activity, and nontoxicity to the tested cells (OSCC). It is found that the activity against bacterium is facilitated by the electrostatic interaction between the positively charged AgNPcols and the negatively charged bacterial membranes. Probably the shape, size and positive zeta potential of AgNPcols facilitates the activity against gram negative bacterium and gram positive bacterium. Furthermore, the cell viability test provides the basics for the future study that aims to investigate the in vivo behaviors of AgNPcols by using biological tissues.

\section{Methods}

Synthesis of collagen-based silver nanoparticles (AgNPcols)

A solution of silver nitrate $\left(\mathrm{AgNO}_{3}\right)$ at a concentration of $108 \mu \mathrm{gAg} / \mathrm{mL}$, a collagen type I from rat tail (Santa Cruz Biotechnology) solution at a concentration of $0.1 \mathrm{mg} / \mathrm{ml}$ and a solution of borohydride $\left(\mathrm{NaBH}_{4}\right)$ at $3.78 \mathrm{mg} / \mathrm{ml}$, prepared using ultrapure water at $44^{\circ} \mathrm{C}$ were used to carry out the synthesis of nanoparticles.

The $\mathrm{AgNO}_{3}$ solution was added to the collagen, both with the same volume and remained under agitation to homogenize for $10 \mathrm{~min}$. The $\mathrm{NaBH}_{4}$ solution was added later, in the form of jet, for any solution of $\mathrm{NaBH}_{4}$, came in contact with the Beker solutions quickly and completely. This solution was stirred for 10 minutes to homogenize. Subsequently, the reaction mixture was centrifuged at $3600 \mathrm{rpm}$ for 15 minutes and finally

Table 2 Minimum inhibitory concentrations (MICs) of AgNPcol ( $\mu \mathrm{g} \mathrm{Ag} / \mathrm{mL}$ ), $\mathrm{AgNO}_{3}$ ( $\mu \mathrm{g} \mathrm{Ag} / \mathrm{mL}$ ), and standard antibiotics $(\mu \mathrm{g} / \mathrm{mL})$ for inhibiting Staphylococcus aureus and Escherichia coli

\begin{tabular}{llllll}
\hline & \multicolumn{2}{l}{ AgNPcol $(\boldsymbol{\mu g A g} / \mathbf{m L})$} & & \multicolumn{2}{l}{ Controls } \\
\hline Bacterial strains & $1: 1$ & $1: 6$ & $1: 15$ & $\mathrm{AgNO}_{3}(\mu \mathrm{gAg} / \mathrm{mL})$ & Antibiotic $(\mu \mathrm{g} / \mathrm{mL})$ \\
S. aureus & 11.7 & 17.4 & 11.7 & 13.5 & $<0.5^{\mathrm{a}}$ \\
E. coli & 11.7 & 8.7 & 11.7 & 6.75 & $<0.5^{\mathrm{b}}$ \\
\hline
\end{tabular}




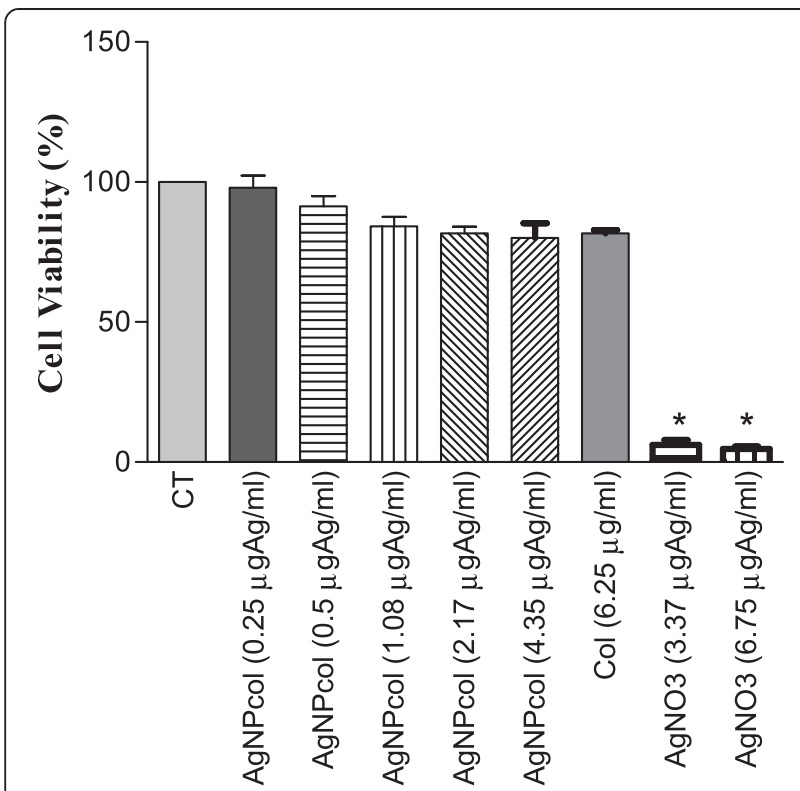

Figure 3 Cell viability. Results of cell viability test of AgNPcol and control solutions ( $\mathrm{Col}$ and $\mathrm{AgNO}_{3}$ ). All data were expressed as mean \pm SEM values of three independent experiments. A value of ${ }^{*} p<0.05$ was considered statistically significance.

separated from the supernatants of the final solution present in the container. In the present study three different proportions of borohydride solution regarding Silver Nitrate $\left(\mathrm{AgNO}_{3}\right)$ (molar ratio: 1:1, $1: 6$ e 1:15) were selected.

\section{Physicochemical characterization of AgNPcols}

The AgNPcols were characterized by UV-vis spectroscopy using a Shimadzu (UV 1800) spectrophotometer. Were subsequently characterized according to their size, electrical potential and PDI using the DLS (Malvern Zetasizer Nano ZS Model 3600) with laser with a wavelength of $633 \mathrm{~nm}$ and scattering angle of $90^{\circ}$ all measurements were performed in triplicate. To verify the shape and confirm the diameter of the nanoparticles non-diluted samples were placed on two screens $(20 \mu \mathrm{L})$ for transmission electron microscopy (TEM) previously coated with Formvar. After drying for $2 \mathrm{~h}$ at room temperature $\left(25 \pm 2^{\circ} \mathrm{C}\right)$ screens were analyzed in a Jeol JEM-1010 electron microscope and photomicrographed by an UltraScan ${ }^{\circ}$ with Digital Micrograph 3.6.5 software (Gatan/USA) [25].

In order to quantify the percentage of silver in solution, the atomic absorption spectroscopy (Varian - Model AA240FS) was used, with a wavelength of $328.1 \mathrm{~nm}$ and multielement lamp (Varian No. 5610108700). The reading was held in atomic absorption flame with Oxygen and Acetylene gases.
XRD data were obtained at the Laboratory of X-ray Crystallography of IFSC/USP using a Rigaku Rotaflex diffractometer equipped with graphite monochromator and rotating anode tube, operating with $\mathrm{Cu} \mathrm{Ka}, 50 \mathrm{kV}$ and $100 \mathrm{~mA}$. Powder diffraction patterns were obtained in step scanning mode, $2 \theta=5-100^{\circ}$, step of $0.02^{\circ}$ and $5 \mathrm{~s} /$ step. Peak Fitting Module program [60] was used for the peak decomposition of the semicrystalline pattern and determination of area due to the amorphous phase.

\section{Evaluation of antibacterial activity of AgNPcols}

To study the antibacterial properties of AgNPcols, by the determination of Minimum Inhibitory Concentration (MIC), two bacterial strains were selected: Staphylococcus aureus ATCC 29213 (Gram-positive) and Escherichia coli ATCC 25922 (Gram-negative). The microorganisms were cultured in Mueller-Hinton agar at $37^{\circ} \mathrm{C}$ for 24 hours in aerobic conditions. Then a suspension of bacterial strains with an optical density of McFarland of $0.5\left(1 \times 10^{8} \mathrm{CFU} / \mathrm{mL}\right)$ was made in an isotonic sodium chloride $0.85 \%$ solution. Later in time, this solution was diluted ten times $\left(1 \times 10^{7} \mathrm{CFU} / \mathrm{mL}\right)$ and used as inoculum in the experiment. MIC was determined according to protocols previously described [61-63] using 96-well microdilution plate with Mueller-Hinton broth where the strains (concentration of $5 \times 10^{5} \mathrm{CFU} / \mathrm{mL}$ ) were exposed to twofold dilution series of the AgNPcols with concentrations ranging from 34,8 to $0,36 \mu \mathrm{gAg} / \mathrm{mL}$. The same procedure was used to determine the MIC of the following controls: collagen, $\mathrm{AgNO}_{3}$, and standard antibiotics effective against the tested bacterial strains with concentrations ranging from 27 to $0.42 \mu \mathrm{gAg} / \mathrm{mL}$ for $\mathrm{AgNO}_{3} ; 50$ to $3,12 \mu \mathrm{g} / \mathrm{mL}$ for collagen and 32 to $0.5 \mu \mathrm{g} / \mathrm{mL}$ for antibiotics. Sterile Mueller-Hinton broth was used as the negative control and inoculated broth was used as the positive control. MIC was defined as the lowest concentration of agent that restricted the visual bacterial growth in the culture media.

\section{Cell viability}

For the study of cell viability, the AgNPcol 1:6 was diluted four times with the ratio of two, starting at a concentration of $4.35 \mu \mathrm{gAg} / \mathrm{ml}$. The cell lines used in this study was oral squamous cell carcinoma (OSCC) obtained from American Type Culture Collection (ATCC, Manassas, VA). Cells were grown in $75 \mathrm{~cm}^{2}$ flasks and maintained in Dulbecco's modified Eagle medium (DMEM) supplemented with $10 \%$ fetal bovine serum, streptomycin/penicillin antibiotics and non-essential aminoacids. For the experiment the cells were seeded in a 96-well plate $(5,000$ cel./ Well) and kept in an incubator (atmosphere at $37^{\circ} \mathrm{C}$ and humidified $5 \% \mathrm{CO}_{2}$ ) for 24 hours. In a 96-well plate was added 5 different concentrations AgNPcol solutions and control solutions (medium, collagen - $6.25 \mu \mathrm{g} / \mathrm{ml}$, AgNO3 $3.37 \mu \mathrm{gAg} / \mathrm{ml}$ and AgNO3 - $6.75 \mu \mathrm{gAg} / \mathrm{ml}$ ). The plates 
were kept in an incubator for 3 hours. Subsequently, the added solutions were removed and placed in Hank's buffer for 5 minutes. The buffer was removed and fresh medium was added. After 24 hours the medium was removed and added to a solution of DMEM without phenol and MTT ([3-(4,5-dimethyl thiazol-2-yl)-2,5-diphenyl tetrazolium bromide) (15\%) to each well. The plates were incubated for 4 hours. Thereafter all the medium with MTT was removed with care to do not remove formazam produced by living cells. Finally, isopropanol was added to each well to solubilize the formazam and taken to review the reader Safire (TECAN EUA Inc., Durham, NC). Statistical analysis was performed using Prism 5.0 (GraphPad Software) by ANOVA and Tukey test. All data were expressed as mean and standard deviation of three independent experiments. We used the statistical significance of $\mathrm{p}<0.05$ for this study [64].

\section{Additional file}

\section{Additional file 1: Additional information about XRD result.}

\section{Abbreviations \\ AgNPs: Silver nanoparticles; AgNPcols: Silver nanoparticles stabilized with type I collagen; $\mathrm{AgNO}_{3}$ : Silver nitrate; $\mathrm{NaBH}_{4}$ : Sodium borohydride; LbL: Layer-by-layer; $\mathrm{Ag}^{\circ}$ : Silver; mM: Millimolar; PDI: Polydispersity index; UV-vis: Ultraviolet-visible; DLS: Dynamic light scattering; TEM: Transmission electron microscopy; FTIR: Fourier transform infrared spectra; XDR: X-ray powder diffraction; MICs: Minimum inhibitory concentrations; CT: Control; Col: Collagen.}

\section{Competing interests}

The authors declare that they have no competing interests.

\section{Authors' contributions}

VSC contributed to the organization and drafting of this article. PVQ, AA, FLP, GGG, ACT, ACM, YPM, JRC, SASK, CE, JRSA, DS and JRSJ contributed to the selection of methodology, analysis and discussion of the results. All authors read and approved the final manuscript.

\section{Acknowledgements}

We thank the Laboratory of Photobiology and Photomedicine of University of São Paulo, the Laboratory of Microscopy of University of Brasília and the Institute of Physics of São Carlos to contribute with this paper. ACM are grateful to FAPESP (2014/02282-6). YPM are grateful to CAPES (AUX-PERM705/2009).

\section{Author details}

${ }^{1}$ Research Center in Biodiversity and Biotechnology (Biotec), Campus Parnaíba, Federal University of Piauí, Av São Sebastian 2819, 64202-020 Parnaíba, Piauí, Brazil. 'Physiotherapy Department, Campus Parnaíba, Federal University of Piauí, Av. São Sebastião 2819, 64202-020 Parnaíba, Piauí, Brazil. ${ }^{3}$ Departamento de Química, Laboratório de Fotobiologia e Fotomedicina, Faculdade de Filosofia, Ciências e Letras de Ribeirão Preto, Universidade de São Paulo, 14040-901, Ribeirão Preto, SP, Brazil. Institute of Physics of São Carlos (IFSC), University of São Paulo (USP), 13566-590 São Carlos, SP, Brazil. ${ }^{5}$ Laboratory of Microscopy, Institute of Biology, University of Brasília, 70910900 Brasília, DF, Brazil. 'Area of Morphology, Faculty of Medicine, University of Brasília, Brasília 70910900DF, Brazil. Interdisciplinary Laboratory for Advanced Materials (LIMAV), Federal University of Piauí, 64049-550 Teresina, PI, Brazil. ${ }^{8}$ Department of Chemistry, Campus Teresina, Federal University of Piauí, 64049-550 Teresina, Piauí, Brazil.
}

Received: 1 July 2014 Accepted: 4 September 2014

Published online: 17 September 2014

\section{References}

1. Dornelles C, Costa S: Estudo comparativo da dissolução de três diferentes marcas de colágeno utilizadas em técnicas cirúrgicas otológicas. Rev Bras Otorrinolaringol 2003, 69:744-751.

2. Tonhi E, Plepis AMG: Obtenção e caracterização de blendas colágenoquitosana. Qim nova 2002, 25:943-948.

3. Lin YC, Tan FJ, Marra KG, Jan SS, Liu DC: Synthesis and characterization of collagen/hyaluronan/chitosan composite sponges for potential biomedical applications. Acta Biomater 2009, 5:2591-2600.

4. Wang $X H$, Li DP, Wang WJ, Feng QL, Cui FZ, Xu YX, Song XH, Van der Werf M: Crosslinked collagen/chitosan matrix for artificial livers. Biomaterials 2003, 24:3213-3220.

5. Nehrer S, Breinan HA, Ramappa A, Young G, Shortkroff S, Louie LK, Sledge $C B$, Yannas IV, Spector M: Matrix collagen type and pore size influence behaviour of seeded canine chondrocytes. Biomaterials 1997, 18:769-776.

6. Nishikawa AK, Taira T, Yoshizato K: In vitro maturation of collagen fibrils modulates spreading, DNA synthesis, and collagenolysis of epidermal cells and fibroblasts. Exp Cell Res 1987, 171:164-177.

7. Heimbach D, Luterman A, Burke J, Cram A, Herndon D, Hunt J, Jordan M McManus W, Solem L, Warden G, Zawacki B: Artificial dermis for major burns. Ann Surg 1988, 208:313-320

8. De Vries HJC, Middelkoop E, Mekkes JR, Dutrieux RP, Wildevuur CHR, Westerhof W: Dermal regeneration in native noncross-linked collagen sponges with diferent extracellular matrix molecules. Wound Repair Regen 1994, 2:37-47.

9. Nevins M, Kirkerhead C, Nevins M, Wozney JA, Palmer R: Bone formation in the goat maxillary sinus induced by absorbable collagen sponge implants impregnated with recombinant human bone morphogenetic protein-2. Int J Periodont Restorative Dent 1996, 16:9-19.

10. Stone KR, Steadman JR, Rodkey WG, Li ST: Regeneration of a meniscal cartilage with use of a collagen scaffold: analysis of preliminary data. J Bone Jt Surg 1997, 79A:1770-1777

11. Speer DP, Chvapil M, Volz RG, Holmes MD: Enhancement of healing in osteochondral defects by collagen sponge implants. Clin Orthop Relat Res 1979, 144:326-335.

12. Natsume T, Ike O, Okada T, Takimoto N, Shimizu Y, Ikada Y: Porous collagen sponge for esophageal replacement. J Biomed Mater Res 1993, 27:867-875

13. Narotam PK, Van Dellen JR, Bhoola KD: A clinicopathological study of collagen sponge as a dural graft in neurosurgery. J Neurosurg 1995, 82:406-412.

14. Van-Wachem PB, Van-Luyn MJA, Costa MLP: Myoblast seeding in a collagen matrix evaluated in vitro. J Biomed Mater Res 1996, 30:353-360

15. Ding T, Lu WW, Zheng Y, Li ZY, Pan HB, Luo Z: Rapid repair of rat sciatic nerve injury using a nanosilver-embedded collagen scaffold coated with laminin and fibronectin. Regen Med 2011, 6:437-447.

16. Matsuda K, Suzuki S, Isshiki N, Yoshioka K, Okada T, Ikada Y: Influence of glycosaminoglycans on the collagen sponge component of a bilayer artificial skin. Biomaterials 1990, 11:351-355.

17. Srivastava S, Gorham SD, French DA, Shivas AA, Courtney JM: In vivo evaluation and comparison of collagen, acetylated collagen and collagen/glycosaminoglycan composite films and sponges as candidate biomaterials. Biomaterials 1990, 11:155-161.

18. Liu W, Deng C, McLaughlin CR, Fagerholm P, Lagali NS, Heyne B, Scaiano JC, Watsky MA, Kato Y, Munger R, Shinozaki N, Li F, Griffith M: Collagenphosphorylcholine interpenetrating network hydrogels as corneal substitutes. Biomaterials 2009, 30:1551-1559.

19. Fagerholm P, Lagali NS, Merrett K, Jackson WB, Munger R, Liu Y, Polarek JW, Söderqvist $M$, Griffith $M$ : A biosynthetic alternative to human donor tissue for inducing corneal regeneration: 24-month follow-up of a phase 1 clinical study. Sci Trans/ Med 2010, 2:46ra61.

20. Perng CK, Wang YJ, Tsi CH, Ma H: In vivo angiogenesis effect of porous collagen scaffold with hyaluronic acid oligosaccharides. J Surg Res 2011, 168:9-15.

21. Bakare RA, Bhan C, Raghavan D: Synthesis and characterization of collagen grafted Poly(hydroxybutyrate-valerate) (PHBV) scaffold for loading of bovine serum albumin capped silver ( $\mathrm{Ag} / \mathrm{BSA})$ nanoparticles 
in the potential use of tissue engineering application. Biomacromolecules 2014, 15:423-435.

22. Jithendra P, Rajam AM, Kalaivani $T$, Mandal $A B$, Rose $C$ : Preparation and characterization of aloe vera blended collagen-chitosan composite scaffold for tissue engineering applications. ACS Appl Mater Interfaces 2013, 5:7291-7298

23. Hackenberg S, Scherzed A, Kessler M, Hummel S, Technau A, Froelich K, Ginzkey C, Koehler C, Hagen R, Kleinsasser N: Silver nanoparticles: evaluation of DNA damage, toxicity and functional impairment in human mesenchymal stem cells. Toxicol Lett 2011, 201:27-33.

24. Shang L, Wang $Y$, Huang $L$, Dong S: Preparation of DNA-silver nanohybrids in multilayer nanoreactors by in situ electrochemical reduction, characterization, and application. Langmuir 2007, 23:7738-7744.

25. Dipankar C, Murugan S: The green synthesis, characterization and evaluation of the biological activities of silver nanoparticles synthesized from Iresine herbstii leaf aqueous extracts. Colloids Surf B 2012, 98:112-119.

26. Neto $E A B$, Ribeiro C, Zucolotto V: Síntese de nanopartículas de prata para aplicação na sanitização de embalagens. In Embrapa. 2008. http://www.clickciencia.ufscar.br/portal/edicao19/Artigo.pdf.

27. Wong KKY, Liu X: Silver nanoparticles-the real "silver bullet" in clinical medicine? Med Chem Commun 2010, 1:125-131.

28. Chaloupka K, Malam Y, Seifalian AM: Nanosilver as a new generation of nanoproduct in biomedical applications. Trends Biotechnol 2010, 28:580-588

29. Ahamed M, Alsalhi MS, Siddiqui MKJ: Silver nanoparticle applications and human health. Clin Chim Acta 2010, 411:1841-1848.

30. Lok C, Ho C, Chen R, He Q, Yu W, Sun H, Tam PK, Chiu J, Che C: Proteomic analysis of the mode of antibacterial action of silver research articles. J Proteome Res 2006, 5:916-924.

31. Shahverdi AR, Fakhimi A, Shahverdi HR, Minaian S: Synthesis and effect of silver nanoparticles on the antibacterial activity of different antibiotics against Staphylococcus aureus and Escherichia coli. Nanomedicine 2007, 3:168-171.

32. Panácek A, Kvítek L, Prucek R, Kolár M, Veceřová R, Pizúrová N, Sharma VK, Nevěcná TJ, Zborill R: Silver colloid nanoparticles: synthesis, characterization, and their antibacterial activity. J Phys Chem B 2006, 110:16248-16253.

33. Gnanadhas DP, Ben Thomas M, Thomas R, Raichur AM, Chakravortty D: Interaction of silver nanoparticles with serum proteins affects their antimicrobial activity in vivo. Antimicrob Agents Chemother 2013 57:4945-4955.

34. Pal S, Tak YK, Song JM: Does the antibacterial activity of silver nanoparticles depend on the shape of the nanoparticle? A study of the Gram-negative bacterium Escherichia coli. Appl Environ Microbiol 2007, 73:1712-1720

35. Morones JR, Elechiguerra JL, Camacho A, Holt K, Kouri JB, Ramírez JT, Yacaman MJ: The bactericidal effect of silver nanoparticles. Nanotechnology 2005, 16:2346-2353.

36. Kwan KHL, Liu X, To MKT, Yeung KWK, Ho C, Wong KKY: Modulation of collagen alignment by silver nanoparticles results in better mechanical properties in wound healing. Nanomedicine 2011, 7:497-504.

37. Alarcon El, Udekwu K, Skog M, Pacioni NL, Stamplecoskie KG, González-Béjar M, Polisetti N, Wickham A, Richter-Dahlfors A, Griffith M, Scaiano JC: The biocompatibility and antibacterial properties of collagen-stabilized, photochemically prepared silver nanoparticles. Biomaterials 2012, 33:4947-4956.

38. Sun Y, Wang L, Sun L, Guo C, Yang T, Liu Z, Xu F, Li Z: Fabrication, characterization, and application in surface-enhanced Raman spectrum of assembled type-I collagen-silver nanoparticle multilayered films. J Chem Phys 2008, 128:074704.

39. Zhang Z, Wu Y: Investigation of the NaBH4-induced aggregation of $\mathrm{Au}$ nanoparticles. Langmuir 2010, 26:9214-9223.

40. Li Y, Douglas EP: Effects of various salts on structural polymorphism of reconstituted type I collagen fibrils. Colloids Surf B 2013, 112:42-50.

41. Sano S, Kato K, Ikada Y: Introduction of functional groups onto the surface of polyethylene for protein immobilization. Biomaterials 1993, 14:817-822
42. Desai V, Kowshik M: Synthesis and characterization of fumaric acid functionalized $\mathrm{AgCl} /$ titania nanocomposite with enhanced antibacterial activity. J Nanosci Nanotechnol 2013, 13:2826-2834.

43. Prasad RY, McGee JK, Killius MG, Suarez DA, Blackman CF, DeMarini DM, Simmons SO: Investigating oxidative stress and inflammatory responses elicited by silver nanoparticles using high-throughput reporter genes in HepG2 cells: effect of size, surface coating, and intracellular uptake. Toxicol In Vitro 2013, 27:2013-2021.

44. Stevanović M, Bračko I, Milenković M, Filipović N, Nunić J, Filipič M, Uskoković DP: Multifunctional PLGA particles containing poly(l-glutamic acid)-capped silver nanoparticles and ascorbic acid with simultaneous antioxidative and prolonged antimicrobial activity. Acta Biomater 2014, 10:151-162.

45. Hebeish A, El-Rafie MH, El-Sheikh MA, Seleem AA, El-Naggar ME: Antimicrobial wound dressing and anti-inflammatory efficacy of silver nanoparticles. Int J Biol Macromol 2014, 65:509-515.

46. Silva T, Pokhrel LR, Dubey B, Tolaymat TM, Maier KJ, Liu X: Particle size, surface charge and concentration dependent ecotoxicity of three organo-coated silver nanoparticles: comparison between general linear model-predicted and observed toxicity. Sci Total Environ 2014, 468-469:968-976.

47. Kim JS, Kuk E, Yu KN, Kim JH, Park SJ, Lee HJ, Kim SH, Park YK, Park YH, Hwang CY, Kim YK, Lee YS, Jeong DH, Cho MH: Antimicrobial effects of silver nanoparticles. Nanomedicine 2007, 3:95-101.

48. Hamouda T, Baker JR: Antimicrobial mechanism of action of surfactant lipid preparations in enteric Gram-negative bacilli. J Appl Microbiol 2000, 89:397-403.

49. Shang L, Nienhaus K, Nienhaus GU: Engineered nanoparticles interacting with cells: size matters. J Nanobiotechnol 2014, 12:5.

50. Baker C, Pradhan A, Parkstis L, Pochan DJ, Shah SI: Synthesis and antibacterial properties of silver nanoparticles. J Nanosci Nanotechnol 2005, 5(2):244-249

51. Saptarshi SR, Duschl A, Lopata AL: Interaction of nanoparticles with proteins: relation to bio-reactivity of the nanoparticle. J Nanobiotechnol 2013, 11:26.

52. Gao X, Gu G, Hu Z, Guo Y, Fu X, Song J: A simple method for preparation of silver dendrites. Colloids Surfaces A Physicochem Eng Asp 2005, 254:57-61.

53. Sileikaitc் A, Prosyčevas I, Puišo J, Juraitis A, Guobienc் A: Analysis of silver nanoparticles produced by chemical reduction of silver salt solution. Mater Sci (Medziagotyra) 2006, 12(4):287-291.

54. Yamamoto SY, Ujiwara KF, Atarai HW: Surface-enhanced Raman scattering from oleate-stabilized silver colloids at a liquid/liquid interface. Anal Sci 2004, 20(September):1347-1352.

55. Zaheer K, Shaeel AA, Abdullah YO, Ziya AK, Abdulrahman AOA Shape-directing role of cetyltrimethylammonium bromide in the preparation of silver nanoparticles. J Colloid Interface Sci 2012, 367:101-108.

56. Lara HH, Garza-Treviño EN, Ixtepan-Turrent L, Singh DK: Silver nanoparticles are broad-spectrum bactericidal and virucidal compounds. J Nanobiotechnol 2011, 9:30.

57. Kato H, Nakamura A, Takahashi K, Kinugasa S: Accurate size and size-distribution determination of polystyrene latex nanoparticles in aqueous medium using dynamic light scattering and asymmetrical flow field flow fractionation with multi-angle light scattering. Nanomaterials 2012, 2:15-30.

58. Gurunathan S, Han JW, Eppakayala V, Jeyaraj M, Kim JH: Cytotoxicity of biologically synthesized silver nanoparticles in MDA-MB-231 human breast cancer cells. Biomed Res Int 2013, 2013:535796.

59. Prokopovich P, Leech R, Carmalt CJ, Parkin IP, Perni S: A novel bone cement impregnated with silver - tiopronin nanoparticles: its antimicrobial, cytotoxic, and mechanical properties. Int J Nanomed 2013, 8:2227-2237.

60. PEAK Fitting Module. Northampton: OriginLab Corporation, One Roundhouse Plaza; 2002.

61. CLSI-Clinical Laboratory Standards Institute: Methods for Dilution Antimicrobial Susceptibility Test for Bacteria that Grow Aerobically. Available online: http://antimicrobianos.com.ar/ATB/wp-content/uploads/2012/11/03CLSI-M07-A9-2012.pdf (accessed on 18 September 2013).

62. Quelemes PV, Araruna FB, de Faria BEF, Kuckelhaus SAS, da Silva DA, Mendonça RZ, Eiras C, Soares MJS, Leite JRSA: Development and 
antibacterial activity of cashew gum-based silver nanoparticles. Int J Mol Sci 2013, 14:4969-4981.

63. Guzman M, Dille J, Godet S: Synthesis and antibacterial activity of silver nanoparticles against gram-positive and gram-negative bacteria. Nanomedicine 2012, 8:37-45.

64. Falqueiro AM, Siqueira-Moura MP, Jardim DR, Primo FL, Morais PC

Mosiniewicz-Szablewska E, Suchocki P, Tedesco AC: In vitro cytotoxicity of Selol-loaded magnetic nanocapsules against neoplastic cell lines under AC magnetic field activation. J Appl Phys 2012, 111:07B335.

doi:10.1186/s12951-014-0036-6

Cite this article as: Cardoso et al:: Collagen-based silver nanoparticles for biological applications: synthesis and characterization. Journal of Nanobiotechnology 2014 12:36.

\section{Submit your next manuscript to BioMed Central and take full advantage of:}

- Convenient online submission

- Thorough peer review

- No space constraints or color figure charges

- Immediate publication on acceptance

- Inclusion in PubMed, CAS, Scopus and Google Scholar

- Research which is freely available for redistribution 